\title{
ON THE CALCIUM UPTAKE OF GLASSHOUSE CUCUMBER
}

\author{
J. E. HÅRDH \\ Horticulture Research Institute, Piikkiö
}

Received October 12, 1957

Cucumber, in Finland an important glasshouse vegetable, sometimes develops growth disorders due to a calcium deficiency. The calcium deficiency symptoms on cucumber have been described by Friedrich and Scholz (4), Kiviniemi (5) and others as follows. The roots of a young plant are poorly developed, thicker and shorter than normal. The roots become brown at an early stage and the root hairs are scarce. The upper leaves of older plants become pale green beginning with the leaf margins, which turn somewhat upwards. Later the areas between the veins turn yellow and the leaves get vaulted. Finally a necrosis spreads from the leaf margin towards the middle of the leaf. The leaves of a calcium deficient plant are smaller than normal while the stem is thin, brittle and with only a few secondary shoots. The flowers are smaller than normal and pale yellow in color. Fruit set is usually fair and the fruits remain small, furrowed and tasteless.

The nutrient uptake of plants is influenced, inter alia, by the calcium content of the soil and by soil acidity. It is well known that $\mathrm{Ca}$ is antagonistic to $\mathrm{K}, \mathrm{Na}$, $\mathrm{Mg}, \mathrm{NH}_{4}$ and $\mathrm{B}$ as nutrients. The uptake of calcium, thus, depends to some extent on the nutrient balance in the soil, and on the $\mathrm{K}, \mathrm{Mg}$ and $\mathrm{B}$ level in it $(1,3)$. If there is too much of these nutrients, the plants are suffering from a calcium deficiency. An excess of calcium, on the other hand, results in a potassium, magnesium and/or boron deficiency. In Finland cucumber is frequently grown in greenhouse soil that is high in potassium and electrolyte concentration due to fertilization during successive years. It was thought that cucumber growing in soil like that might suffer from a calcium shortage, and preliminary tests were, therefore, made at the Horticulture Research Institute in 1957 to investigate the calcium uptake in soils with a high electrolyte concentration and an abundant potassium and magnesium content. The tests were carried out using $\mathrm{Ca}^{45}$-labelled $\mathrm{CaO}$.

The test plants, variety Butchers, were sown 5.6. and potted 19.6. into $4^{\prime \prime}$ pots, the salts were added and the labelled $\mathrm{CaO}$ was mixed in the soil before planting. The dose for each plant consisted of $0.2 \mathrm{mC}$ of $\mathrm{Ca}^{45}$ in treatments $1-4$ (cf. Table). The activity on each of the leaves was determined once a week using a Philips' Geigertube 18513 (window $31.7 \mathrm{~mm}^{2}$ ). 


\section{Uptake of calcium}

The calcium uptake of cucumber, according to the results, is hampered by high soil conductivity. During four weeks the plants in treatment 4, with a high electrolyte and potassium content in the soil, received only half as much calcium as the plants in treatments $1-3$ with soil conductivity below 4 and a low potassium content (1.6-2.4 tons/ha). An addition of magnesium into the soil (cf. treatments 1 and 2) diminished significantly the calcium uptake.

In 4 weeks from the beginning of the test, marked differences in the size of the plants could be seen (Fig. 1). The plants in treatment 1 were somewhat larger than the 0-plants possibly owing to the $\left(\mathrm{NH}_{4}\right)_{3} \mathrm{PO}_{4}$ fertilization. In treatments $2-4$ the growth was weaker than that of the 0 - and 1-plants, the growth in treatment 4 being very poor because of a high salt concentration in the soil. These plants showed, in addition, a clear discoloration of the leaves thus indicating a calcium deficiency.

Table I. Salt additions, soil analysis and the uptake of $\mathrm{Ca}^{45}$ in 4 weeks expressed as counts/min. (means of 6 plants). Psf $=$ superphosphate, $\mathrm{K}_{50}=$ potassium chloride. $\mathrm{I}-\mathrm{VI}=$ first-sixth leaf. All plants were treated with $1.7 \mathrm{~g}$. $\mathrm{CaO}\left(\mathrm{Ca}^{45}\right)$ except those of treatment 0 , whose counts represent the background radiation.

\begin{tabular}{|c|c|c|c|c|c|c|c|c|c|c|c|c|c|c|c|}
\hline \multirow{2}{*}{$\begin{array}{l}\text { Treat- } \\
\text { ment }\end{array}$} & \multicolumn{4}{|c|}{ Salt additions g./plant } & \multicolumn{2}{|c|}{ Soil analysis } & \multirow{2}{*}{$\begin{array}{l}\text { tons/ha } \\
\mathrm{CaCO}_{3}\end{array}$} & \multirow{2}{*}{$\begin{array}{l}\text { Soil } \\
\text { conduc- } \\
\text { tivity }\end{array}$} & \multirow[b]{2}{*}{$\mathrm{pH}$} & \multicolumn{6}{|c|}{$\mathrm{Ca}^{45}$ as counts $/ \mathrm{min}$. } \\
\hline & (NI & $\mathrm{PO}_{4}$ & $\mathrm{MgSO}_{4}$ & $\mathrm{KNO}_{3}$ & Psf & $\mathrm{K}_{50}$ & & & & I & II & III & IV & V & VI \\
\hline 0 & $\mathbf{0}$ & 0 & 0 & 3.9 & 2.4 & 2.4 & 22.7 & 1.1 & 6.8 & 10 & 8 & 7 & 6 & 7 & 8 \\
\hline 1 & 10 & 0 & 0 & 12.0 & 1.6 & 1.6 & 28.0 & 1.4 & 6.5 & 139 & 123 & 103 & 92 & 72 & 59 \\
\hline 2 & 10 & 20 & 0 & 14.4 & 2.0 & 2.0 & 20.6 & 2.8 & 6.2 & 119 & 118 & 90 & 66 & 60 & 48 \\
\hline 3 & 10 & 20 & 10 & 13.2 & 2.4 & 2.4 & 21.9 & 3.8 & 6.0 & 121 & 119 & 104 & 87 & 55 & 54 \\
\hline 4 & 10 & 20 & 20 & 10.8 & 8.0 & 8.0 & 21.5 & 5.7 & 6.2 & 76 & 91 & 71 & 75 & 49 & 44 \\
\hline
\end{tabular}

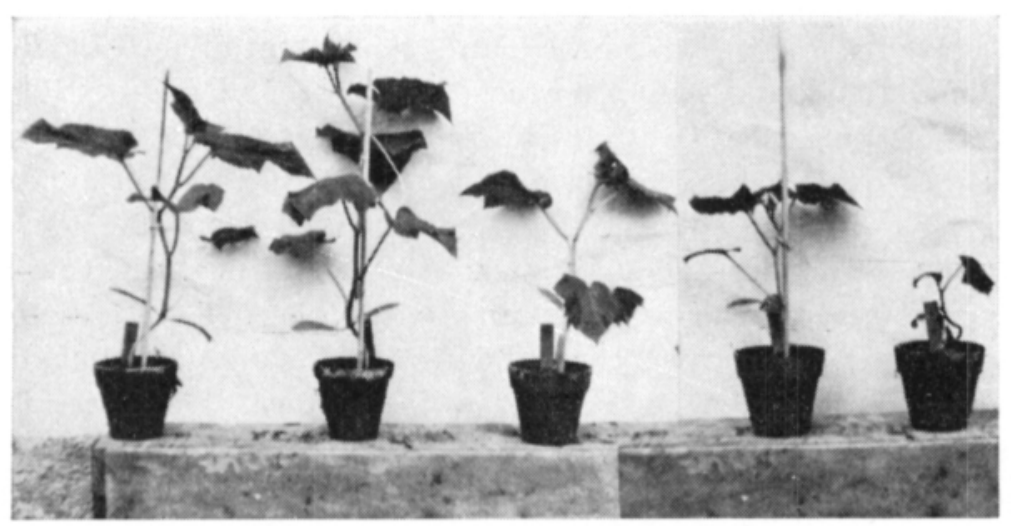

Fig. 1. Size of plants in treatments (from left) $0,1,2,3$ and 4 in four weeks (cf. Table). 
Calcium is accumulated, according to the investigations of BIDDULPH (2) et al. into the lower leaves. This element, in similarity with boron, iron and perhaps others, is only slowly transferred from the lower parts of the plant into the meristemal zone, and the younger tissues, therefore, might suffer from a deficiency despite a sufficient supply of these elements within the plant. The results of the tests described show that calcium accumulates in the lowest and oldest leaves of cucumber (Fig. 2), in the same way as in many other plants. The Ca-content of the first leaf in treatment 1 was thus twice as high as the content in the corresponding leaf in treatment 4 , the differences in the upper leaves being small. This seems to indicate that calcium deficiency symptoms appear or dont appear on the upper leaves irrespective of the Ca-content of these but depending on that in the lower leaves, and that Ca might have a distinctive function in the cucumber plant possibly in the assimilation process.

Autoradiographs (Fig. 3) prepared 18 days after the beginning of the tests show that radiation caused by $\mathrm{Ca}^{45}$ occurs only in small pits, the areas between the pits being totally free from radiation exposure. The pits on the stem and leaf veins were $0.5-1.0 \mathrm{~mm}$. apart and irregularly scattered in the radiograph. In the leaf surface between the veins the pits were smaller and more crowded.

In the large parenchymatous cells, close to the vessels of the cucumber stem, mostly lens shaped crystals occur. The cells of the leaves are somewhat smaller and the crystals therefore, in the leaf tissue more crowded than in the stem and petiole. The chemical nature of the crystals has not been determined, but they are taken to be calcium salts, as on many other plants. The pits. visible in the radiographs, might be due to crystals containing radiocalcium.

The calcium uptake of cucumber, according to the results presented, is strikingly dependent on some of the factors influencing the general nutrient uptake of plants. High electrolyte concentration in the soil (conductivity) retards the growth and metabolism as well as the calcium uptake. An excess of potassium and of magnesium, which are antagonistic elements to calcium, diminishes the calcium uptake, a well established fact. Earlier it has been shown, too, that calcium accumulates in the lower and older parts of the plant, the content of $\mathrm{Ca}$ being lower in the meristemal zone. In plants, some of which had an abundance of calcium (treatment 1) and some only very small amounts (treatment 4 ), the Ca-content in the upper leaves was about equal, the former plants were healthy in appearance the latter, however, showing symptoms of a Ca-deficiency. It is possible, therefore, that the most important effect of calcium in a cucumber plant might be connected with assimilation processes, which are more intensive in the older leaves than in the growing ones. If the older leaves contain sufficient $\mathrm{Ca}$, the meristemal zone does not show deficiency symptoms indicating a Ca-shortage. Otherwise typical Cadeficiency symptons appear. $\mathrm{Ca}$ is accumulated in pits, according to the radiographs, clearly apart from each other and occurring more frequently in the leaves than on the stem. The author suggests. therefore, that the pits are due to calcium oxalate, malonate or other crystals labelled with $\mathrm{Ca}^{45}$. Since no $\mathrm{Ca}^{45}$ could be found 


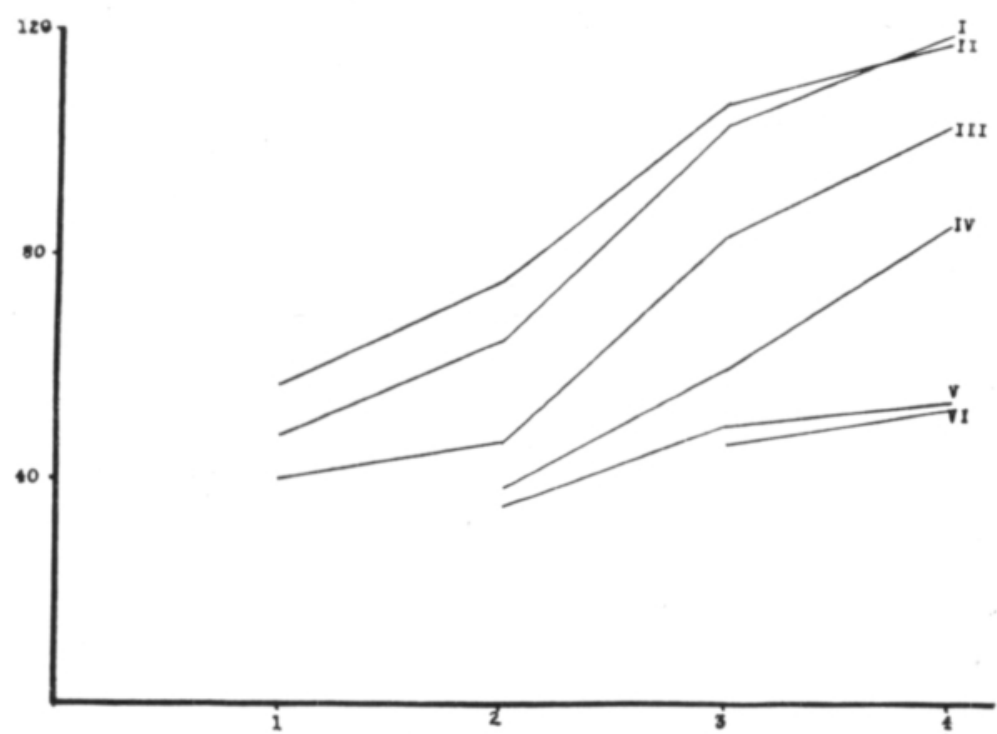

Fig. 2. Distribution of $\mathrm{Ca}^{45}$ in the 1st, 2nd, 3rd and 4th week as means of 6 plants in treatment 3 (cf. Table). I-VI = first-sixth leaf.

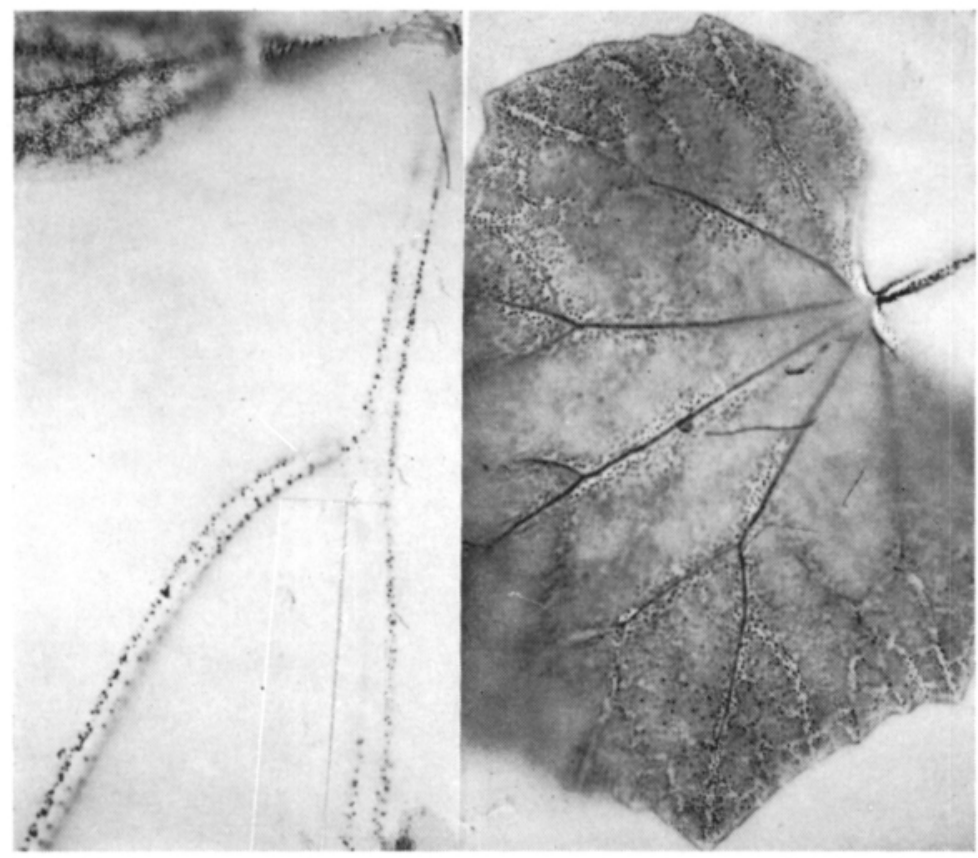

Fig. 3. Autoradiographs showing part of stem (left) and of leaf (right) with the pits of exposure due to radiocalcium. 
between the pits, it is thought that the main duty of calcium on cucumber is to neutralize the harmful by-products of the $\mathrm{CO}_{2}$-assimilation. When this happens in a sufficient degree in the lower leaves, no deficiency symptoms occur on the upper leaves. If, on the contrary, lower leaves contain less than normal $\mathrm{Ca}$, the harmful by-products of assimilation processes, e.g. some acids, are translocated into other parts of the plant causing growth disorders and discoloration known as Ca-deficiency symptoms.

\section{I T E R A T U R E}

(1) Alten, F. \& ORTh, H. 1940. Wasserkulturversuche zur Kalk-Kali-frage. Die Ernährung der Pflanze 36: 13-16.

(2) Biddulph, O. 1951. The translocation of minerals in plants. E. TRUOG, Mineral nutrition of plants, 261-275. Richmond.

(3) Dojmi Di Dilupis, S. 1936. Úber die Bedeutung des physiologischen Antagonismus zwischen Kalzium und Magnesium für das Pflanzenwachstum. Z. Pflanzenernährung, Düngung u. Bodenkunde 45: $296-303$.

•(4) Friedrich, G. \& Scholz, H. 1953. Die Kultur von Treibhausgurken in Nährlösungen. 52 S. Berlin. (5) Kiviniemi, E. 1957. Kalsiumin pute kasvihuonekurkulla [Calcium deficiency on glasshouse cucumber]. Puutarha-uutiset 16: 242.

S E L O S T U:

\section{KASVIHUONEKURKUN KALSIUMINOTOSTA}

\section{J. E. HÅrdH}

\section{Puutarhantutkimuslaitos, Piikkiö}

Kalsiumin puutteessa olevan kasvihuonekurkun juuret ovat normaalia lyhyemmät ja paksummat ruskettuen normaalia aikaisemmin. Ylälehdet vaalenevat ennen alalehtiä kiertyen samalla ylöspäin. Värinmuutos alkaa lehden reunoista sekä suonien välistä. Lehdet sekä kukat ovat tavallista pienemmät ja kukkien väri vaalean keltainen. Hedelmănmuodostus saattaa hidastua, jolloin ne jäävät normaalia pienemmiksi ja mauttomiksi.

Kasvien ravinnonottoon vaikuttaa mm. kalsiumin runsaus maassa. Kalium, natrium, magnesium, ammonium ja boori ovat antagonisteja kalsiumille, mikä merkitse, että kalsiumin otto häiriintyy, jos maassa on runsaasti mm. kaliumia tai magnesiumia. Runsas kalkitus puolestaan vaikeuttaa näiden sekã boorin ottoa. Kasvihuonekurkkua viljellään usein mullassa, jota on lannoitettu vuodesta toiseen ja jonka suolapitoisuus siitä syystä on korkea. Puutarhantutkimuslaitoksella todettiin v. 1957 suoritetuissa tutkimuksissa, että mullan korkea johtoluku sekä runsas kalin määrä vähentävät kalsiumin $\left(\mathrm{Ca}^{45}\right)$ ottoa (taul., koejäsenet $1-3$ ja 4). Myös magnesiumin lisääminen vähensi kasvien Ca-pitoisuutta. Koejäsenessä 4, jossa mullan johtoluku oli korkein, oli kasvien kasvu heikointa (kuva 1). Niissä ilmeni lisäksi kloroosia sekä lehtien reunojen kiertymistä, jollaista kurkulle voi aiheuttaa kalsiumin puute.

Kalsium kerääntyy runsaimmin kasvin vanhimpiin lehtiin, joissa assimilaatio on vilkkainta, ja siirtyy niistä hitaasti kasvuvyöhykkeeseen ja nuoriin lehtiin (kuva 2). Autoradiogrammeissa, jotka tehtiin $\mathrm{Ca}^{45}$ :ä saaneista kasveista, ilmeni, että kalsium kerääntyy kasvissa aluksi pisteiksi (kuva 3). Näitä oli lehden solukossa tiheämmässä kuin varressa ja lehtiruodissa, ja on ajateltavissa, että pisteet johtuvat oksalaatti-, malonaatti- tai muista kalsiumsuolakiteistä. Tämän mukaan näyttäisi kalsiumin eräänä tärkeänä tehtävänä kurkussa olevan hiilihydraattisynteesin yhteydessä kehittyvien haitallisten happojen neutraloiminen. Mikäli tätä ei tapahdu, voivat haitalliset aineet kulkeutua alalehdistä ylempiin ja aiheuttaa niissä kloroosia ja kasvun häiriintymistä. 